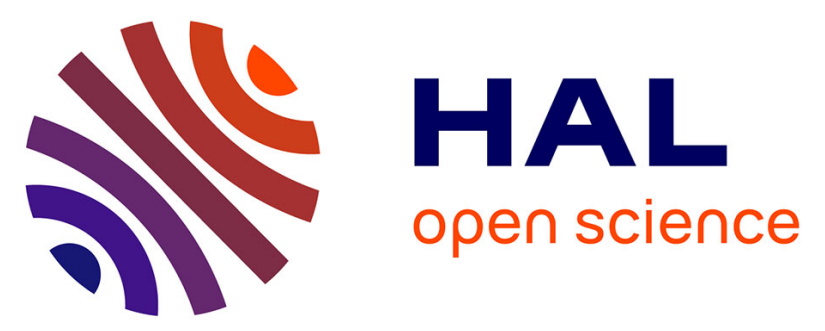

\title{
MIDWATER TUNICATES - ARE THEY RELATED TO THE PERMANENT FRONT OF THE LIGURIAN SEA (NW MEDITERRANEAN)
}

G Gorsky, Nl Dasilva, S Dallot, P Laval, Jc Braconnot, L Prieur

\section{- To cite this version:}

G Gorsky, Nl Dasilva, S Dallot, P Laval, Jc Braconnot, et al.. MIDWATER TUNICATES - ARE THEY RELATED TO THE PERMANENT FRONT OF THE LIGURIAN SEA (NW MEDITERRANEAN). Marine Ecology Progress Series, 1991, 74 (2-3), pp.195-204. 10.3354/meps074195 . hal03284979

\section{HAL Id: hal-03284979 \\ https://hal.science/hal-03284979}

Submitted on 13 Jul 2021

HAL is a multi-disciplinary open access archive for the deposit and dissemination of scientific research documents, whether they are published or not. The documents may come from teaching and research institutions in France or abroad, or from public or private research centers.
L'archive ouverte pluridisciplinaire HAL, est destinée au dépôt et à la diffusion de documents scientifiques de niveau recherche, publiés ou non, émanant des établissements d'enseignement et de recherche français ou étrangers, des laboratoires publics ou privés. 


\title{
Midwater tunicates: are they related to the permanent front of the Ligurian Sea (NW Mediterranean)?
}

\author{
G. Gorsky ${ }^{1}$, N. Lins da Silva ${ }^{1}$, S. Dallot ${ }^{1}$, Ph. Laval ${ }^{1}$, J. C. Braconnot ${ }^{1}$, L. Prieur $^{2}$ \\ ${ }^{1}$ URA 716, CNRS, B.P. 28, F-06230 Villefranche-sur-mer, France \\ ${ }^{2}$ URA 353, CNRS, B.P. 08, F-06230 Villefranche-sur-mer, France
}

\begin{abstract}
Midwater filter feeders may play an important role in the downward carbon flux by aggregating particulate organic matter into large, slowly sinking mucoid aggregates or rapidly sinking fecal material. Successive submersible cruises made in the frontal zone of the Ligurian Sea showed the presence of midwater ( 400 to $800 \mathrm{~m}$ ) populations of a not yet described larvacean species of the genus Oikopleura and of the thaliacean Salpa fusiformis Cuvier The vertical stratification of autotrophic and heterotrophic organisms and the occurrence of autotrophic microphytoplankton at aphotic depths suggested that food supply for midwater filter feeders was actively transported by the frontal circulation from the subsurface layers along the inclined isopycnals. Minimum flow velocity for renewal of organic carbon at the midwater stratum was estimated to be $20 \mathrm{~m} \mathrm{~d}^{-1}$. The vertical distribution of the midwater filter-feeder community corresponded to the deep origins of peripheral (near the coast) and central divergences and may indicate the deep junction of convection cells.
\end{abstract}

\section{INTRODUCTION}

Our concepts of oceanic mesopelagic life are based mainly on samples taken with trawls, nets and pumps. These techniques unfortunately destroy fragile organisms, whose identity and ecological roles frequently remain unknown. In order to better understand midwater biological activity, more information and new methods are needed. The use of manned submersibles for observation and sampling of pelagic organisms is a technique that alleviates these problems (Youngbluth et al. 1990). Bathyscaphe observations made in the mid1950 's (Suzuki \& Kato 1953) and later (for review see Mills $\&$ Goy 1988) revealed diverse and often abundant populations of macroplankton in deep layers. New species are still being collected and described (Madin \& Harbison 1978, Mackie \& Mills 1983, Mills et al. 1987, Pugh \& Harbison 1987, Pugh \& Youngbluth 1988, Fenaux \& Youngbluth 1990). In situ studies allow vertical stratification and population densities of mesozooplankton to be analyzed (Youngbluth 1984, Mackie 1985, Mills \& Goy 1988, Laval et al. 1989), and their metabolic rates measured (Youngbluth et al. 1988). Submersibles have also been utilized for investigations of marine snow (Silver \& Alldredge 1981, Alldredge \& Youngbluth 1985).

We report here results from the MIGRAGEL II sub- mersible cruise carried out from 14 to 22 May 1988 in the Ligurian Sea (NW Mediterranean). Reports of a previous cruise, MIGRAGEL I, indicated the presence of an unexpected larvacean population in midwater depths (Laval et al. 1989). During the MIGRAGEL II cruise these observations were confirmed and extended. A population of filter-feeding tunicates, including a new larvacean species, Oikopleura villafrancae $e^{*}$ and the salp Salpa fusiformis Cuvier, were found at midwater depths. The following characteristics of these pelagic tunicates suggest that their roles in the pelagic ecosystem may be important:

(1) In optimal feeding conditions larvaceans and salps form dense blooms (Braconnot 1971, Seki 1973, Taguchi 1982, Le Borgne 1983, Deibel 1985). High individual growth rates and short life cycles yield rapid population growth (Heron 1972, Fenaux 1976, Heron \& Benham 1985, Fenaux et al. 1986, Le Borgne \& Moll 1986, Braconnot et al. 1988, Gorsky \& Palazzoli 1989). (2) Both groups are important producers of organic matter and have high defecation rates (Bruland \& Silver 1981, Iseki 1981, Madin 1982, Taguchi 1982). Larvaceans can secrete and discard as many as 15

- A description of this new midwater oikopleurid is currently being prepared by R. Fenaux 
houses per day (Gorsky 1980, Fenaux 1985). The size of a mucous house is species-and age-dependent and varies from $1 \mathrm{~mm}$ to more than $1 \mathrm{~m}$ in diameter (Barham 1979). (3) Larvaceans and salps can retain particles as small as 0.1 and 0.7 um respectively (Hamner et al. 1975, Flood 1979, Deibel \& Turner 1985). Both groups show high filtering rates (Harbison \& Gilmer 1976 , Paffenhöfer 1976, Harbison \& McAlister 1979, Alldredge 1981, Mullin 1983, Madin \& Cetta 1984, Andersen 1985, Deibel 1988). (4) About $30 \%$ of particles filtered by the larvacean are not ingested but remain in the discarded house (Gorsky et al. 1984). Larvaceans filter non-selectively and thus microbial populations are introduced and develop in the house (Davoll \& Silver 1986). The house forms, therefore, a rich organic particulate environment.

Considering the above, high larvacean and salp abundances observed at midwater depths during the Iand II cruises suggest: (a) that the dietary requirements of these populations were satisfied, (b) that by aggregation of small particles, they may influence the size distribution and the composition of particles in suspension in the water column. The purposes of this paper are: (i) to describe the nature and the origin of the trophic environment harvested by these organisms, and (ii) to discuss the role of the Ligurian front in the maintenance of this population.

\section{MATERIAL AND METHODS}

During the 'MIGRAGEL II' cruise 8 dives were conducted to a maximum depth of $970 \mathrm{~m}$ using the submersible 'Cyana' (IFREMER, France). Accompanying research vessels were 'Le Suroit' and 'Korotneff'. The

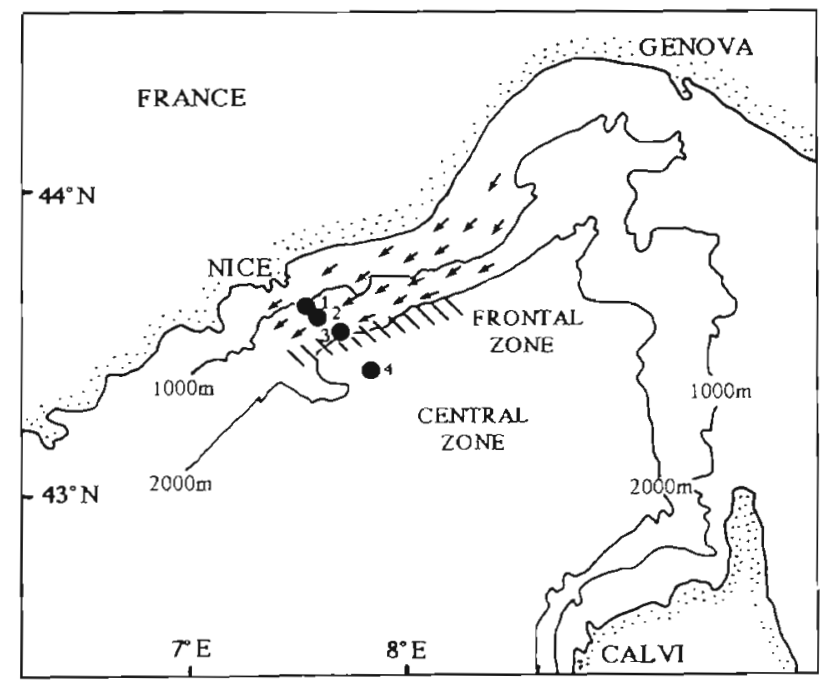

Fig. 1 The Ligurian Sea, showing the diving locations of the MIGRAGEL II cruise. Ligurian Current is shown by arrows; frontal zone is hatched dive stations were located between Cape Ferrat (France) and Calvi (Corsica) (Fig. 1). Stns 1, 2, 3 and 4 were situated $6,8,13$ and 23 nautical miles, respectively, offshore from Cape Ferrat (Table 1). Three submersible dives were performed during the night and 5 during the day. All dives were video-recorded. One CTD cast $(0$ to $800 \mathrm{~m}$ ) was performed at each of the 4 stations with a Guildline probe, model 8705. On 20 May 1988 , a vertical profile of water (0 to $600 \mathrm{~m}$ ) was taken at Stn 3 using Niskin bottles by RV 'Korotneff'. Since the time spent at each diving station ( 6 to $12 \mathrm{~h}$ ) was not sufficient for a complete CTD section through the frontal zone, we also used data obtained from the PROS VI program (PROSpection mer Ligure; Prieur et al. 1990) carried out at the beginning of June 1988. Fortunately, the meteorological and hydrological conditions were remarkably stable between the second half of May 1988 and 1 June. On this latter date, a series of hydrological profiles were performed as a part of the PROS VI program $3,8,13,18,23$ and 28 n miles offshore. We used this complete section across the frontal structure for Fig. 2. The similarity of hydrological structures between mid-May and 1 June is shown in Table 2.

Gelatinous filter-feeder concentrations (mean distances between individuals) were estimated according to a modified method of Mackie \& Mills (1983). Two $500 \mathrm{~W}$ spotlights were directed towards a $50 \mathrm{~cm}$ long graduated bar (10 cm graduations) mounted $120 \mathrm{~cm}$ in front of the observer. One of the cameras was focused on the bar and this 2-dimensional surface was used for density calculations during horizontal sections of the stair-like descent of the submersible (Laval et al. 1989). Two 6.51 translucent detritus samplers (Tietze \& Clark 1986) were employed to trap organisms. On board, captured organisms were rapidly transferred from the samplers and fixed in $4 \%$ buffered formaldehyde. Samples for bacterio-, pico- and nanoplankton counting were fixed in Borax-buffered formalin (final concentration $4 \%$ ) and processed according to Porter \& Feig's DAPI method (1980). Microphytoplankton and ciliates were preserved in Lugol's iodine solution $2 \% \mathrm{v} / \mathrm{v}$, and counted using the Utermöhl sedimentation technique. Chlorophyll a was measured using a Turner 111 fluorometer, Particulate matter from water samples was filtered first through 100 um Nytrel net and finally through precombusted Whatman GF/C filters, and frozen in liquid nitrogen.

We partitioned the living components of the marine food web into 6 groups: (a) microphytoplankton (MPH), unicellular phytoplankton of the size range $>20 \mu \mathrm{m}$, consisting mainly of diatoms, dinoflagellates and silicoflagellates, (b) autotrophic nanoflagellates (ANF), plastidic flagellates of a diameter from 2 to $20 \mu \mathrm{m}$, (C) cyanobacteria (CYA), (d) heterotrophic bacteria (HBE), (e) heterotrophic nanoflagellates (HNF), aplastidic flagellates with diameters from 2 to $20 \mu \mathrm{m}$, and (f) 
Table 1. Summary of diving stations and shallowest observations of mesopelagic filter-feeders. O. v. Oikopleura villafrancae

\begin{tabular}{|c|c|c|c|c|c|c|c|c|c|}
\hline $\begin{array}{l}\text { Dive } \\
\text { No. }\end{array}$ & $\begin{array}{l}\text { Date } \\
\text { (1988) }\end{array}$ & Station & $\begin{array}{l}\text { Miles } \\
\text { offshore }\end{array}$ & Location & $\begin{array}{l}\text { Dive start } \\
\quad(\mathrm{h})\end{array}$ & $\begin{array}{l}\text { Dive } \\
\text { end } \\
\text { (h) }\end{array}$ & $\begin{array}{l}\text { Max. } \\
\text { depth } \\
(m)\end{array}$ & $\begin{array}{c}\text { Shallowest } \\
\text { O. v. } \\
\text { (m) }\end{array}$ & $\begin{array}{c}\text { Shallowest } \\
\text { salp } \\
\text { (m) }\end{array}$ \\
\hline 1 & 14 May & 1 & 6 & $43^{\circ} 37.7^{\prime} \mathrm{N}, 7^{\circ} 26.6^{\prime} \mathrm{E}$ & $21: 41$ & $02: 00$ & 615 & 350 & 410 \\
\hline 2 & $15 \mathrm{May}$ & 2 & 8 & $43^{\circ} 35.6^{\prime} \mathrm{N}, 7^{\circ} 29.4^{\prime} \mathrm{E}$ & $21: 40$ & $01: 53$ & 625 & 370 & 380 \\
\hline 3 & $16 \mathrm{May}$ & 1 & 6 & $43^{\circ} 37.2^{\prime} \mathrm{N}, 7^{\circ} 26.6^{\prime} \mathrm{E}$ & 2111 & $01: 30$ & 625 & 360 & 400 \\
\hline 4 & 17 May & 2 & 8 & $43^{\circ} 35.6^{\prime} \mathrm{N}, 7^{\circ} 29.4^{\prime} \mathrm{E}$ & $14: 50$ & $19: 22$ & 590 & 400 & 380 \\
\hline 5 & $19 \mathrm{May}$ & 4 & 23 & $43^{\circ} 27.8^{\prime} \mathrm{N}, 7^{\circ} 46.8^{\prime} \mathrm{E}$ & $09: 33$ & 14.16 & 692 & 650 & 680 \\
\hline 6 & $20 \mathrm{May}$ & 3 & 13 & $43^{\circ} 32.8^{\prime} \mathrm{N}, 7^{\circ} 35.2^{\prime} \mathrm{E}$ & $10: 30$ & $15: 10$ & 610 & 510 & 480 \\
\hline 7 & 21 May & 2 & 8 & $43^{\circ} 35.9^{\prime} \mathrm{N}, 7^{\circ} 28.8^{\prime} \mathrm{E}$ & $09: 48$ & $14: 45$ & 970 & 440 & 500 \\
\hline 8 & $22 \mathrm{May}$ & 2 & 8 & $43^{\circ} 36.0^{\prime} \mathrm{N}, 7^{\circ} 39.2^{\prime} \mathrm{E}$ & $09: 15$ & 11.25 & 457 & 450 & 400 \\
\hline
\end{tabular}

Table 2. Location, date and isopycnal depths obtained by CTD casts during the MIGRAGEL II cruise in mid-May and the PROS VI cruise on 1 June 1988. Station numbers are those of the PROS VI cruise. Geographic location and distance from Cape Ferrat are indicated in local time [UT (Universal Time) +2]. MIGRAGEL dive no. corresponds to the submersible dive number from Table 1 Subheadings under 'Isopycnal depths' are density excesses $\left(\mathrm{kg} \mathrm{m}^{-3}\right)$

\begin{tabular}{|c|c|c|c|c|c|c|c|c|c|}
\hline \multirow{2}{*}{$\begin{array}{l}\text { PROS VI } \\
\text { cast no. }\end{array}$} & \multirow[t]{2}{*}{ Cruise } & \multirow[t]{2}{*}{ Location } & \multirow{2}{*}{$\begin{array}{c}\text { MIGRAGEL } \\
\text { dive no. }\end{array}$} & \multirow{2}{*}{$\begin{array}{l}\text { Date } \\
\text { (1988) }\end{array}$} & \multirow{2}{*}{$\begin{array}{l}\text { Local } \\
\text { time } \\
\text { (h) }\end{array}$} & \multirow{2}{*}{$\begin{array}{l}\text { Distance } \\
\text { from shore } \\
\text { (miles) }\end{array}$} & \multicolumn{3}{|c|}{ Isopycnal depths $(\mathrm{m})$} \\
\hline & & & & & & & 28.80 & 28.90 & 29.00 \\
\hline 6 & PROS VI & $43^{\circ} 38.1^{\prime} \mathrm{N}, 7^{\circ} 23.2^{\prime} \mathrm{E}$ & - & 1 June & $09: 55$ & 3 & 140 & 200 & 350 \\
\hline- & MIGRAGEL & $43^{\circ} 37.2^{\prime} \mathrm{N}, 7^{\circ} 26.6^{\prime} \mathrm{E}$ & 3 & 16 May & $23: 46$ & 6 & 158 & 198 & 295 \\
\hline 5 & PROS VI & $43^{\circ} 35.2^{\prime} \mathrm{N}, 7^{\circ} 28.6^{\prime} \mathrm{E}$ & - & 1 June & $11: 44$ & 8 & 71 & 100 & 250 \\
\hline - & MIGRAGEL & $43^{\circ} 35.6^{\prime} \mathrm{N}, 7^{\circ} 29.4^{\prime} \mathrm{E}$ & 4 & 17 May & $21: 49$ & 8 & 142 & 192 & 270 \\
\hline 4 & PROS VI & $43^{\circ} 32.6^{\prime} \mathrm{N}, 7^{\circ} 34.5^{\prime} \mathrm{E}$ & - & 1 June & $14: 08$ & 13 & 45 & 79 & 180 \\
\hline- & MIGRAGEL & $43^{\circ} 32.8^{\prime} \mathrm{N}, 7^{\circ} 35,2^{\prime} \mathrm{E}$ & 6 & 20 May & $16: 35$ & 13 & 42 & 84 & 158 \\
\hline 3 & PROS VI & $43^{\circ} 30.1^{\prime} \mathrm{N}, 7^{\circ} 40.9^{\prime} \mathrm{E}$ & - & 1 June & $16: 01$ & 18 & 43 & 49 & 60 \\
\hline 2 & PROS VI & $43^{\circ} 27.6^{\prime} \mathrm{N}, 7^{\circ} 46.9^{\prime} \mathrm{E}$ & - & 1 June & $17: 46$ & 23 & 48 & 55 & 71 \\
\hline- & MIGRAGEL & $43^{\circ} 27.8^{\prime} \mathrm{N}, 7^{\circ} 46.8^{\prime} \mathrm{E}$ & 5 & 19 May & $23: 19$ & 23 & 48 & 55 & 66 \\
\hline 1 & PROS VI & $43^{\circ} 24.7^{\prime} \mathrm{N}, 7^{\circ} 52.5^{\prime} \mathrm{E}$ & - & 1 June & $20: 01$ & 28 & 28 & 39 & 70 \\
\hline
\end{tabular}

oligotrichous ciliates and tintinnids (CIL). The biomass of these groups in each sample is given in Table 3.

Conversion factors for calculation of carbon biomass from biovolume ( $C$. Vol. ratio) were used according to Fuhrman \& Azam (1980), Strathmann (1967), Putt \& Stoecker (1989), Wiadnyana \& Lins da Silva (unpubl.) and Verity \& Langdon (1984), for bacteria, flagellates, oligotrichous ciliates, phytoplankton and tintinnids, respectively.

\section{RESULTS}

\section{Distribution of filter feeders}

The MIGRAGEL I and MIGRAGEL II cruises found and confirmed previously unknown spatial stratifications of the midwater zooplankton community. Visual observations made in the aphotic zone during the MIGRAGEL II cruise revealed the presence of several larvacean and salp species from the surface down to $970 \mathrm{~m}$. A high density ( 2 to 3 chains $\mathrm{m}^{-3}$ ) of salps, mainly Salpa fusiformis Cuvier and Ihlea punctata (Forssk.), was observed in the upper $50 \mathrm{~m}$ at Stns 1 and
2. Just below this layer 2 larvacean species were numerous in the water column, Oikopleura albicans Leuckart and $O$. fusiformis Fol. The diameter of the most frequently observed houses was ca $3 \mathrm{~cm}$

Starting at a depth of ca 350 m near the coast at Stn 1 and at ca $650 \mathrm{~m}$ at Stn 4 (23 miles offshore; Fig. 2), a larvacean population belonging to a new species, Oikopleura villafrancae (Fig. 3), became dominant. The spatial distribution of this population was patchy and its population density varied between 1 and 10 ind. $\mathrm{m}^{-3}$ during the MIGRAGEL II cruise (detailed information on the spatial distribution of zooplankton will be published elsewhere; Laval, Braconnot \& Lins da Silva unpubl.). The diameter of observed houses was estimated to vary between 3 and $6 \mathrm{~cm}$. The upper limit of occurrence of these filter feeders descended with increasing distance from the shore. Five specimens of the new species were collected. Their trunk size varied between 3 and $4 \mathrm{~mm}$. The mouth opening of this size class reached ca $300 \mu \mathrm{m}$ diameter.

In the same layer different developmental stages of Salpa fusiformis, short blastozooid chains, oozooids and blastozooids with embryos were observed with a swim- 
Table 3. Composition of water samples taken by the submersible 'Cyana' during the MIGRAGEL II cruise and by Niskin bottles from the RV 'Korotneff' on 20 May 1988 ('). MPH: microphytoplānkton (>20 um); ANF: plastidic nanoflagellates (2 to $20 \mu m)_{i}$ CYA: cyanobacteria; HBE: heterotrophic bacteria; HNF; aplastidic nanoflagellates ( 2 to 20 um); CIL: oligotrichous ciliates and tintinnids; AFDW: ash-free dry weight; $\mathrm{ml}^{-1}$ : organisms per $\mathrm{ml}$

\begin{tabular}{|c|c|c|c|c|c|c|c|c|c|c|}
\hline Station & $\begin{array}{c}\text { Date } \\
\text { (1988) }\end{array}$ & $\begin{array}{l}\text { Depth } \\
(\mathrm{m})\end{array}$ & $\begin{array}{l}\mathrm{HBE} \\
(\mathrm{ppm})\end{array}$ & $\begin{array}{c}\text { CYA } \\
\text { (ppm) }\end{array}$ & $\begin{array}{l}\text { ANF } \\
(\mathrm{ppm})\end{array}$ & $\begin{array}{l}\text { HNF } \\
\text { (ppm) }\end{array}$ & $\begin{array}{c}\mathrm{CIL} \\
(p p m)\end{array}$ & $\begin{array}{c}\text { MPH } \\
\text { (ppm) }\end{array}$ & $\begin{array}{c}\text { AFDW } \\
\left(\mathrm{mg} \mathrm{l}^{-1}\right)\end{array}$ & $\begin{array}{c}\mathrm{Chl} a \\
\left(\mu \mathrm{g} \mathrm{l^{-1 }}\right)\end{array}$ \\
\hline 1 & 16 May & 450 & 0.005 & $3.00 \times 10^{-5}$ & 0.00 & $2.00 \times 10^{-5}$ & 0.00 & 0.026 & - & 0.03 \\
\hline 2 & 22 May & 0 & 0.010 & $2.80 \times 10^{-3}$ & $1.74 \times 10^{-2}$ & $6.15 \times 10^{-2}$ & $2.39 \times 10^{-3}$ & 0.117 & 0.417 & 0.23 \\
\hline 2 & $22 \mathrm{May}$ & 75 & 0.021 & $2.30 \times 10^{-3}$ & $5.07 \times 10^{-2}$ & $7.30 \times 10^{-2}$ & $1.00 \times 10^{-3}$ & 0.001 & 0.468 & 0.65 \\
\hline 2 & 17 May & 418 & 0.004 & $2.00 \times 10^{-5}$ & $9.00 \times 10^{-4}$ & $3.20 \times 10^{-3}$ & $8.00 \times 10^{-5}$ & 0.006 & 0.411 & 0.04 \\
\hline 2 & $22 \mathrm{May}$ & 450 & 0.009 & $1.60 \times 10^{-3}$ & $3.54 \times 10^{-2}$ & $3.11 \times 10^{-2}$ & $4.60 \times 10^{-4}$ & 0.000 & 0.313 & 0.03 \\
\hline 2 & $21 \mathrm{May}$ & 490 & 0.004 & $3.00 \times 10^{-5}$ & $1.25 \times 10^{-2}$ & $5.62 \times 10^{-2}$ & $3.90 \times 10^{-1}$ & 0.006 & 0.127 & 0.02 \\
\hline 3 & 21 May & 509 & 0.004 & $2.00 \times 10^{-5}$ & 0.00 & $2.10 \times 10^{-3}$ & $5.60 \times 10^{-4}$ & 0.000 & - & - \\
\hline 3 & $20 \mathrm{May}^{\circ}$ & 0 & 0.010 & $2.10 \times 10^{-3}$ & $2.09 \times 10^{-2}$ & $7.76 \times 10^{-2}$ & $5.00 \times 10^{-4}$ & 0.031 & 0.611 & 0.18 \\
\hline 3 & $20 \mathrm{May}^{\circ}$ & 50 & 0.012 & $1.90 \times 10^{-3}$ & $7.95 \times 10^{-2}$ & $8.10 \times 10^{-2}$ & $8.90 \times 10^{-3}$ & 0.001 & - & 0.39 \\
\hline 3 & $20 \mathrm{May}^{*}$ & 100 & 0.001 & $1.00 \times 10^{-4}$ & $1.29 \times 10^{-2}$ & $1.88 \times 10^{-2}$ & $3.20 \times 10^{-3}$ & 0.001 & - & 0.08 \\
\hline 3 & 20 May" & 200 & 0.005 & $4.00 \times 10^{-5}$ & $1.70 \times 10^{-3}$ & $8.80 \times 10^{-3}$ & $2.39 \times 10^{-3}$ & 0.006 & - & 0.06 \\
\hline 3 & $20 \mathrm{May}^{\circ}$ & 300 & 0.005 & $2.00 \times 10^{-5}$ & $7.06 \times 10^{-4}$ & $7.01 \times 10^{-3}$ & $2.05 \times 10^{-4}$ & 0.012 & - & 0.03 \\
\hline 3 & $20 \mathrm{May}^{\circ}$ & 400 & 0.006 & $1.00 \times 10^{-5}$ & $9.00 \times 10^{-4}$ & $6.10 \times 10^{-3}$ & $2.95 \times 10^{-3}$ & 0.001 & - & 0.01 \\
\hline 3 & $20 \mathrm{May}$ & 500 & 0.005 & 0.00 & $7.00 \times 10^{-4}$ & $7.70 \times 10^{-3}$ & $8.44 \times 10^{-4}$ & 0.007 & - & 0.02 \\
\hline 3 & 20 May $^{\circ}$ & 570 & 0.004 & 0.00 & 0.00 & $1.60 \times 10^{-3}$ & $4.00 \times 10^{-5}$ & 0.006 & 0.251 & 0.02 \\
\hline 3 & $20 \mathrm{May}^{*}$ & 600 & 0.005 & $1.00 \times 10^{-5}$ & $2.00 \times 10^{-4}$ & $5.20 \times 10^{-3}$ & $2.74 \times 10^{-4}$ & 0.018 & - & 0.02 \\
\hline 4 & 19 May & 0 & - & - & - & - & - & - & 0.635 & 0.34 \\
\hline 4 & 19 May & 300 & 0.006 & $1.30 \times 10^{-4}$ & $1.10 \times 10^{-3}$ & $7.10 \times 10^{-3}$ & $1.00 \times 10^{-4}$ & 0.002 & - & - \\
\hline 4 & 19 May & 680 & 0.004 & $1.00 \times 10^{-5}$ & $2.00 \times 10^{-4}$ & $4.50 \times 10^{-3}$ & $1.10 \times 10^{-4}$ & 0.012 & 0.218 & 0.04 \\
\hline Station & $\begin{array}{c}\text { Date } \\
\text { (1988) }\end{array}$ & $\begin{array}{l}\text { Depth } \\
\text { (m) }\end{array}$ & $\begin{array}{c}\mathrm{HBE} \\
\left(\mathrm{ml^{-1 }}\right)\end{array}$ & $\begin{array}{l}\text { CYA } \\
\left(\mathrm{ml}^{-1}\right)\end{array}$ & $\begin{array}{c}\text { ANF } \\
\left(\mathrm{ml}^{-1}\right)\end{array}$ & $\begin{array}{c}\text { HNF } \\
\left(\mathrm{ml}^{-1}\right)\end{array}$ & $\begin{array}{c}\mathrm{ClL} \\
\left(\mathrm{ml}^{-1}\right)\end{array}$ & $\begin{array}{c}\mathrm{MPH} \\
\left(\mathrm{ml}^{-1}\right)\end{array}$ & $\begin{array}{c}\text { AFDW } \\
\left(\mathrm{mg} \mathrm{l}^{-1}\right)\end{array}$ & $\begin{array}{c}\text { Chla } \\
\left(\mu \mathrm{I}^{-1}\right)\end{array}$ \\
\hline 1 & 16 May & 450 & $1.18 \times 10^{5}$ & $1.43 \times 10^{2}$ & 0.00 & 9.98 & 0.00 & 0.96 & - & 0.03 \\
\hline 2 & $22 \mathrm{May}$ & 0 & $2.54 \times 10^{5}$ & $1.38 \times 10^{4}$ & $2.23 \times 10^{2}$ & $9.58 \times 10^{3}$ & 2.90 & 1.53 & 0.417 & 0.23 \\
\hline 2 & $22 \mathrm{May}$ & 75 & $5.17 \times 10^{5}$ & $1.17 \times 10^{4}$ & $1.05 \times 10^{3}$ & $1.68 \times 10^{3}$ & $1.00 \times 10^{-3}$ & 0.21 & 0.468 & 0.65 \\
\hline 2 & 17 May & 418 & $1.08 \times 10^{5}$ & $1.10 \times 10^{2}$ & $4.86 \times 10^{2}$ & $1.23 \times 10^{2}$ & $2.00 \times 10^{-2}$ & 0.16 & 0.411 & 0.04 \\
\hline 2 & 22 May & 450 & $2.35 \times 10^{5}$ & $8.10 \times 10^{3}$ & $8.05 \times 10^{2}$ & $8.35 \times 10^{2}$ & $3.00 \times 10^{-2}$ & 0.17 & 0.313 & 0.03 \\
\hline 2 & $21 \mathrm{May}$ & 490 & $1.04 \times 10^{5}$ & $1.40 \times 10^{2}$ & $1.33 \times 10^{1}$ & 9.98 & $6.00 \times 10^{-2}$ & 0.05 & 0.127 & 0.02 \\
\hline 3 & $21 \mathrm{May}$ & 509 & $1.02 \times 10^{5}$ & $3.66 \times 10^{1}$ & 0.00 & $8.65 \times 10^{1}$ & $4.00 \times 10^{-5}$ & 0.13 & - & - \\
\hline 3 & 20 May. & 0 & $2.59 \times 10^{5}$ & $1.05 \times 10^{4}$ & $5.25 \times 10^{2}$ & $2.61 \times 10^{3}$ & $4.00 \times 10^{-2}$ & 4.10 & 0.611 & 0.18 \\
\hline 3 & $20 \mathrm{May}^{*}$ & 50 & $1.98 \times 10^{5}$ & $9.28 \times 10^{3}$ & $2.57 \times 10^{3}$ & $3.05 \times 10^{3}$ & 1.39 & 0.10 & - & 0.39 \\
\hline 3 & $20 \mathrm{May}^{*}$ & 100 & $1.69 \times 10^{4}$ & $6.02 \times 10^{2}$ & $2.56 \times 10^{2}$ & $4.13 \times 10^{2}$ & $3.00 \times 10^{-2}$ & 0.12 & - & 0.08 \\
\hline 3 & $20 \mathrm{May}^{\circ}$ & 200 & $1.35 \times 10^{5}$ & $2.13 \times 10^{2}$ & $2.50 \times 10^{2}$ & $2.76 \times 10^{2}$ & $5.00 \times 10^{-2}$ & 0.20 & - & 0.06 \\
\hline 3 & 20 May $^{*}$ & 300 & $1.28 \times 10^{5}$ & $9.31 \times 10^{1}$ & $1.33 \times 10^{1}$ & $1.66 \times 10^{2}$ & $2.05 \times 10^{-4}$ & 0.16 & - & 0.03 \\
\hline 3 & $20 \mathrm{May}^{*}$ & 400 & $1.60 \times 10^{5}$ & $5.99 \times 10^{1}$ & $1.33 \times 10^{1}$ & $1.66 \times 10^{2}$ & $1.00 \times 10^{-2}$ & 0.23 & - & 0.01 \\
\hline 3 & $20 \mathrm{May}^{\circ}$ & 500 & $1.28 \times 10^{5}$ & $1.66 \times 10^{1}$ & 9.98 & $1.73 \times 10^{2}$ & $1.20 \times 10^{-1}$ & 0.31 & - & 0.02 \\
\hline 3 & $20 \mathrm{May}$ & 570 & $1.04 \times 10^{5}$ & 0.00 & 0.00 & $5.99 \times 10^{1}$ & $2.00 \times 10^{2}$ & 0.56 & 0.251 & 0.02 \\
\hline 3 & $20 \mathrm{May}^{*}$ & 600 & $1.19 \times 10^{5}$ & $6.65 \times 10^{1}$ & 3.33 & $1.87 \times 10^{2}$ & $3.00 \times 10^{-2}$ & 0.13 & - & 0.02 \\
\hline 4 & 19 May & 0 & - & - & - & - & - & - & 0.635 & 0.34 \\
\hline 4 & 19 May & 300 & $1.59 \times 10^{5}$ & $6.32 \times 10^{1}$ & $1.66 \times 10^{1}$ & $2.86 \times 10^{2}$ & $1.00 \times 10^{-2}$ & 0.43 & - & - \\
\hline 4 & 19 May & 680 & $9.81 \times 10^{4}$ & $5.32 \times 10^{1}$ & 3.33 & $1.36 \times 10^{2}$ & $4.00 \times 10^{-2}$ & 0.22 & 0.218 & 0.04 \\
\hline
\end{tabular}

ming pattern characteristic of feeding individuals. The size of the observed oozoids exceeded $15 \mathrm{~mm}$ and the size of blastozooids exceeded $25 \mathrm{~mm}$. The concentration of $S$. fusiformis in midwater depths was highest at the 8 mile location, where the estimated number varied between 5 and 30 per $100 \mathrm{~m}^{3}$. At other stations the concentration varied between 1 and 5 ind. $100 \mathrm{~m}^{-3}$.

\section{Composition of water column}

At Stns 1 and 2, the mid-water filter feeders were observed in a layer which corresponded to a water mass situated between the thermal minimum of the cold, winter water (density excess of ca $28.90 \mathrm{~kg} \mathrm{~m}^{-3}$ ) and the thermal maximum of the intermediate water $(29.06 \mathrm{~kg}$ $\mathrm{m}^{-3}$ ). At $\operatorname{Stn} 1$, the top of the midwater layer containing filter feeders began at $350 \mathrm{~m}$ (larvaceans at $350 \mathrm{~m}$, salps at $400 \mathrm{~m}$ ). At $450 \mathrm{~m}$ depth, where the highest concentration of tunicates was observed, microphytoplankton was relatively abundant $\left(0.026 \times 10^{6} \mathrm{\mu m}^{3} \mathrm{ml}^{-1}\right.$; Table 3 , Fig. 2). At Stn 2, Oikopleura villafrancae appeared at $360 \mathrm{~m}$ depth and $S$. fusiformis $20 \mathrm{~m}$ deeper. The layer between 400 and $500 \mathrm{~m}$ was rich in plastidic and aplastidic nanoflagellates (ANF and HNF), $0.035 \times 10^{6}$ $\mu \mathrm{m}^{3} \mathrm{ml}^{-1}$ at $450 \mathrm{~m}$ and $0.056 \times 10^{6} \mu \mathrm{m}^{3} \mathrm{ml}^{-1}$ at $490 \mathrm{~m}$, respectively At Stn 2 below $800 \mathrm{~m}$ another larvacean species, Pelagopleurasp., became dominant (ca 1 house 
Fig. 2. Vertical section (0 to 800 $\mathrm{m})$ of density excess $\left(\mathrm{kg} \mathrm{m}^{-3}\right)$ on the Cape Ferrat - Calvi transect as obtained from the PROS VI data, 1 June 1988. Under the pycnocline the density front was located between 13 and 18 miles offshore. The advective circulation was situated along isopycnal lines having a slope greater than $1 \%$ between 18 and 8 miles offshore (arrow). Black histogram $=$ total living biomass $(\mathrm{ppm}$ $\times 100)$ in the sample, open histogram $=$ biomass $(\mathrm{ppm} \times 100)$ of autotrophic microphytoplankton (MPH) in the sample. (•) Shallowest observation of the larvacean Oikopleura villafrancae; ( $\mathbf{\sigma})$ shallowest midwater observation of the thaliacean Salpa fusiformis. Note that the depth of the midwater tunicate layer increased with distance from shore

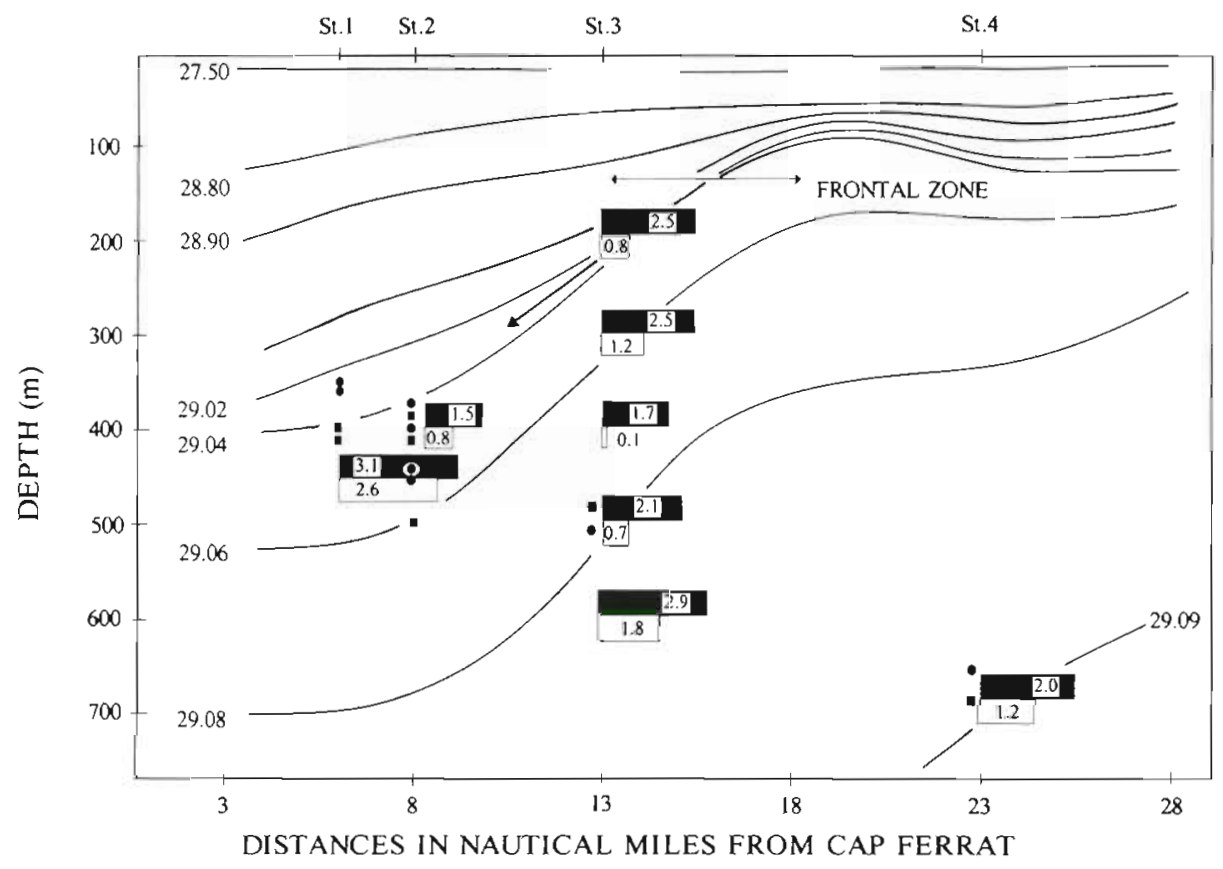

$\mathrm{m}^{-3}$, ca $3 \mathrm{~cm}$ diameter; observation by $\mathrm{M}$. Youngbluth). At $\operatorname{Stn} 3$ the upper limit of the salp stratum began at 480 $m$ depth. The mesopelagic $O$. villafrancae population appeared at $510 \mathrm{~m}$ depth. At these latter depths the hydrological conditions are characterized by a weakly stratified layer of intermediate and deep water having a density excess of more than $29.08 \mathrm{~kg} \mathrm{~m}^{-3}$. At $510 \mathrm{~m}$ we found a biomass of $0.018 \times 10^{6} \mu^{3} \mathrm{ml}^{-1}$ of microphytoplankton cells apparently in good living conditions. At Stn 4, mesopelagic larvaceans were observed at $650 \mathrm{~m}$ and salps appeared $30 \mathrm{~m}$ deeper. At this $680 \mathrm{~m}$ depth the biomass of the living microphytoplankton was $0.012 \times 10^{6} \mu^{3} \mathrm{ml}^{-1}$.

In 20 May profiles of chlorophyll $a$, estimated carbon biomass of autotrophs (MPH, ANF, CYA) and heterotrophs (HBE, HNF, CIL) at Stn 3 (13 miles; Fig. 4), reached their maximum values at a depth of $50 \mathrm{~m}$. The numerical domination of heterotrophic organisms over the autotrophic ones is common in a post-bloom period. The minimum values for the autotroph $\mathrm{MPH}$ and ANF occurred at $400 \mathrm{~m}$, where an increase was observed for the heterotrophic component.

\section{DISCUSSION}

\section{Hydrology}

In the study area, the Ligurian Current, which is about $30 \mathrm{~km}$ wide and ca $150 \mathrm{~m}$ deep (Béthoux \& Prieur 1984, Béthoux et al. 1988), flows southwestward along the coast. A subsurface density front (Sournia et al. 1990) separates the central water mass from the Ligu-
Fig. 3. Photograph taken at $500 \mathrm{~m}$ depth from the submersible 'Cyana' showing an Oikopleura villafrancae (house ca $5 \mathrm{~cm}$ in diameter). Note the high concentration of particles in its environment. I: Incurrent coarse filter; F: food-concentrating filter; $T$ : trunk of the larvacean 


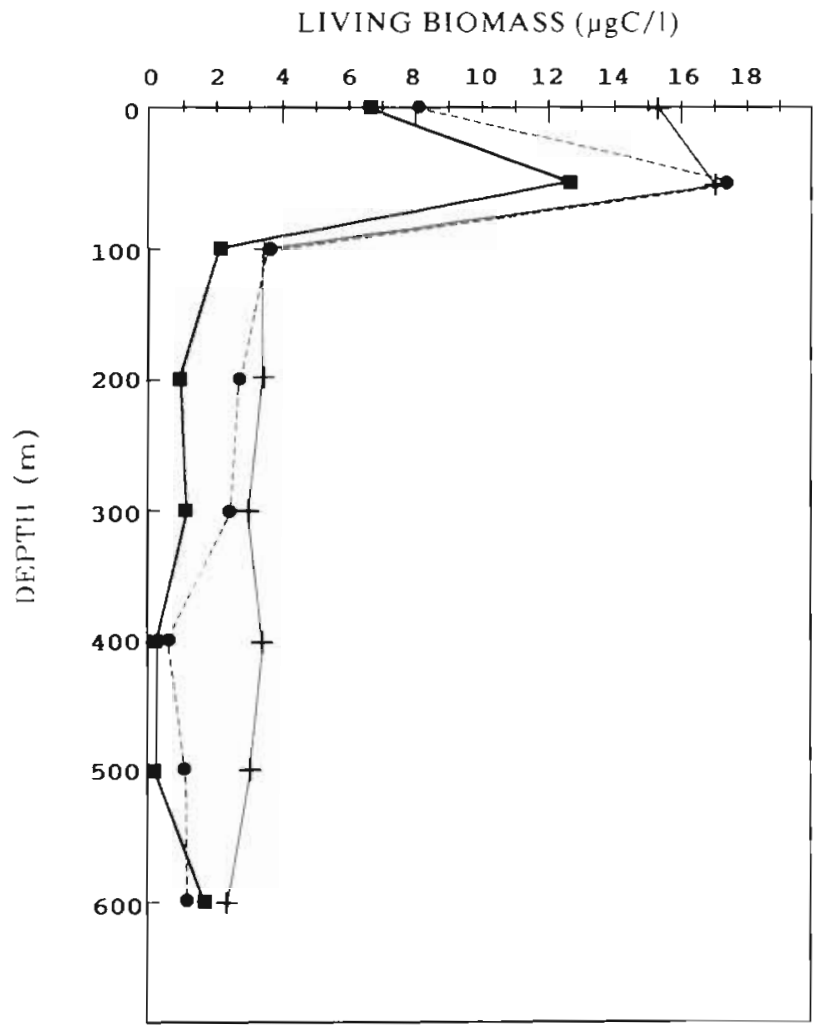

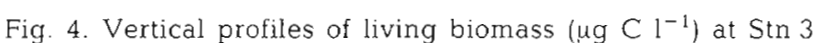
sampled by RV 'Korotneff' on 20 May 1988. ( $\backsim$ ) Autotrophs, (+) heterotrophs, $(\bullet)$ chlorophyll a $\times 45$ (constant used for the Mediterranean phytoplankton)

rian Current (Fig. 1). The Ligurian Current, defined as the primary circulation, induces a secondary circulation, which is assumed to be constituted by 2 convection cells with a common downwelling convergent part along the inclined isopycnals. Boucher et al. (1987) presented a vertical circulation scheme mainly active in the frontal zone as suggested by the recurrently observed spatial distribution of physical, chemical and biological parameters. The convergence which mediates the biomass downward (Fig. 2) is generally encountered in the maximum of the horizontal density gradient (see Boucher et al. 1987, Figs. 4, 5 \& 6). During the MIGRAGEL II cruise this maximum was located between 13 and 18 miles offshore at depths between 50 and $150 \mathrm{~m}$. This maximum of the horizontal density gradient is considered to constitute the origin of the downwelled biomass (indicated by an arrow in Fig. 2). Temperature and salinity values observed at the diving stations are consistent with those obtained on 1 June. To facilitate the comparisons, the same isopycnals were drawn in Fig. 2 (PROS VI casts, 1 June) and in Fig. 5 (diving stations, mid-May). Comparison of isopycnal depths are shown in Table 2. The differences observed at the 8 mile location are probably due to the meandering of the Ligurian Current (Soumia et al. 1990). Data

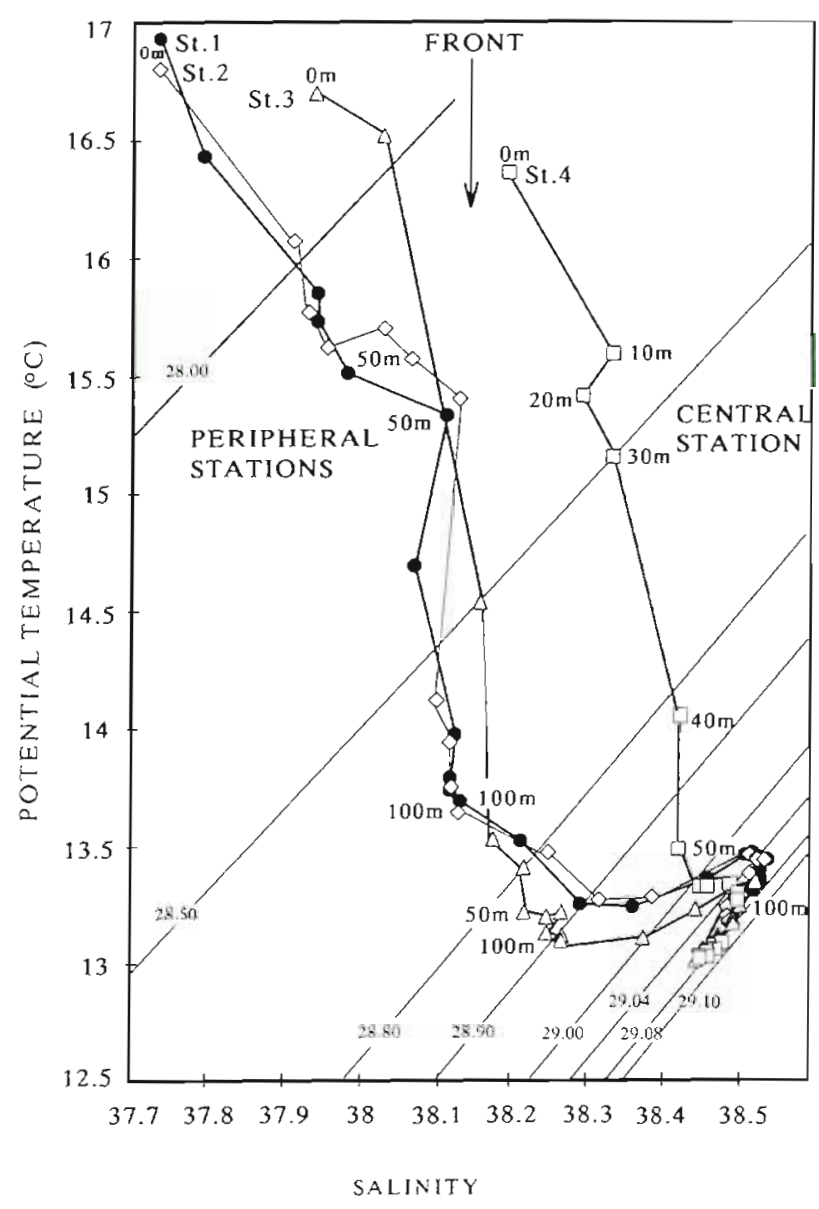

Fig. 5. T-S profiles of the 4 diving stations, drawn from data taken every $10 \mathrm{~m}$ in the upper $100 \mathrm{~m}$ layer and every $50 \mathrm{~m}$ between 100 and $800 \mathrm{~m}$. Isopycnals are drawn here for comparison with the isopycnals in Fig. 2. Stns 1, $2 \& 3$ are peripheral (near the coast) stations and have similar $\mathrm{T}-\mathrm{S}$ profiles. Stn 4 is central (outer side of the front) and is characterized by surface salinity (38.2) much higher than at the 3 peripheral stations. Note that the densities at similar depths are lower at peripheral stations than at the central one

from the long-term survey program PROS VI (Prieur et al. 1990) suggest that this hydrological structure of the Ligurian front is permanent. This feature is essential for the development of the specific zooplankton community described in the present paper.

\section{Ecological considerations}

Similar estimates for the cold water Oikopleura vanhoeffeni Lohmann and warm water Stegosoma magnum Langerhans indicate that the clearance rate of species acclimated to a given temperature is more sizethan temperature-dependent (Alldredge 1981, Deibel 1988). In addition, Knoechel \& Steel-Flynn (1989) found a negative relationship between filtering rate and temperature for $O$. vanhoeffeni. However, it is 
extremely difficult to assess the behavioral stress of larvaceans during experimental work in situ or in the laboratory (Alldredge 1976, pers. obs.). O. villafrancae belongs to the family Oikopleuridae, as do Stegosoma magnum and $O$. vanhoeffeni, and has a similar feeding behavior. We estimate then the filtration rate of a nonmature $O$. villafrancae of $3 \mathrm{~mm}$ trunk length as $300 \mathrm{ml}$ $\mathrm{h}^{-1}$, in the range of values published for the 2 former species.

The carbon content of ingestible sized living cells in aphotic depths at Stn 3 was ca $4 \mu \mathrm{g} \mathrm{Cl}{ }^{-1}$ (Fig. 4). At this concentration the upper limit of the daily filtering rate would be $28.8 \mu \mathrm{g} \mathrm{C}$ per individual. If $30 \%$ of filtered material remains in the abandoned house and is not ingested by the larvacean (Gorsky et al. 1984 for Oikopleura dioica Fol.), the daily ingestion rate of living carbon will attain $20.2 \mu \mathrm{gg}$ ind $^{-1}$. During the MIGRAGEL II cruise we observed a population of large larvacean Oikopleura albicans in the upper $600 \mathrm{~m}$ of the water column. We suppose that the metabolic activities of $O$. albicans and $O$. villafrancae harvesting at the same time in a similar environment are comparable. An O. albicans of $3 \mathrm{~mm}$ trunk length contains $210 \mu \mathrm{g} \mathrm{C}$ (G. Gorsky unpubl.). The percentage of daily ration ( $\mu$ g ingested $C \times \mu$ g body $C^{-1} \times 100$ ) derived from the living biomass available at the sampled depths will then reach $9.8 \%$ of body carbon. According to Deibel (1986) and Alldredge (1976) the carbon content of a clean house without filtered material represents 10 to $20 \%$ of the body weight. It is therefore clear that the living food biomass found at midwater depths is not the main nutritional source of the midwater larvaceans.

Larvaceans are non-selective suspension feeders. If the ash free dry weight/organic carbon ratio of the organic matter at the studied area is 2.5 (G. CopinMontégut pers. comm.), then $418 \mathrm{~m}$ deep (Stn 2) the water contains $160 \mathrm{\mu g}$ organic $\mathrm{C}^{-1}$ and at $680 \mathrm{~m}$ (Stn 4), $80 \mu \mathrm{g} \mathrm{Cl}^{-1}$. After multiplying the filtration ratio by 0.70 (non-ingested particles), the maximum potential daily ration attains $806 \mu \mathrm{g} \mathrm{C}$ or $384 \%$ of body carbon for an individual at depth $418 \mathrm{~m}$ and $403 \mu \mathrm{g}$ Cor $192 \%$ of body carbon at $680 \mathrm{~m}$. If mesopelagic larvaceans discard 4 houses per day (observed for Oikopleura albicans at $13^{\circ} \mathrm{C}$ ), then 40 to $80 \%$ of body carbon is used daily for house secretion and the remaining part of the ration for metabolism, growth and reproduction.

The presence of living microphytoplankton in aphotic layers indicated that organic matter, which allowed development of filter-feeders at the observed depths, originated from the surface or from the subsurface layers and was transported to deeper layers.

Our observations show that: (1) a non-negligible biomass of living algal cells was observed in the apho- tic layer containing a permanent and specific filterfeeder community; (2) organic particulate matter in suspension and not living cells constituted the main diet of midwater larvaceans: (3) Oikopleura villafrancae did not appear above an inclined layer, $350 \mathrm{~m}$ near the coast at Stn 1 and $680 \mathrm{~m}$ at Stn 4 (Fig. 2).

Fowler et al. (1987), using an automatic time-series particle trap moored 15 miles off the coast of Calvi (Corsica), reported a rapid removal of Chemobyl fallout from surface waters to deeper layers. The presence of these radionuclides at $200 \mathrm{~m}$ a few days after the fallout could not be explained by settling of small particles.

Assuming that the entire food supply for midwater tunicates is of surface origin, we can estimate the minimum vertical flow velocity required to renew the organic carbon stock which maintains the populations of midwater filter-feeders. Net vertical flux is equal to the consumption rate of these filter-feeders and can be estimated from:

$$
W\left(C_{1}-C_{2}\right) S=n R S H
$$

where $W=$ the vertical component of the velocity; $C_{1}=$ concentration of organic carbon entering the tunicate stratum; $C_{2}=$ concentration of organic carbon leaving this layer; $S=$ entry and outlet surface; $n=$ number of filter-feeders per unit volume; $R=$ daily carbon ration of filter-feeders; $H=$ vertical extent of the tunicate stratum (Fig. 6).

At Stn 2 the tunicate stratum began at a depth of ca $400 \mathrm{~m}$ and ended at a depth of about $800 \mathrm{~m}$. The mean estimated daily ration of an individual was about

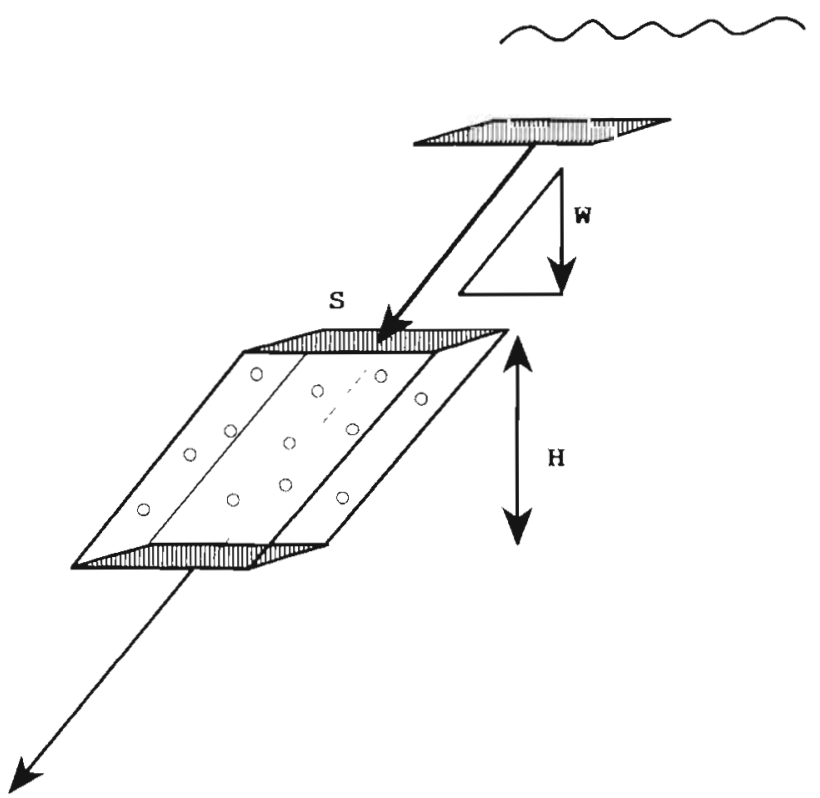

Fig. 6. Scheme of the midwater tunicate layer and of the water flow induced by the frontal circulation. S: Surface; W: vertical component of the flow velocity: $H$ : depth of midwater filterfeeder stratum 
$0.8 \mathrm{mg} \mathrm{C} \mathrm{d}^{-1}$ and the subsurface carbon concentration was determined to be about $160 \mathrm{mg} \mathrm{C} \mathrm{m}^{-3}$. If we consider that $C_{2}=0$ or $C_{1}-C_{2}=160 \mathrm{mg} \mathrm{C} \mathrm{m}^{-3}$, then $W=n R H /\left(C_{1}-C_{2}\right)=10 \times 0.8 \mathrm{mg} \mathrm{C} \times 400 / 160 \mathrm{mg} \mathrm{C}=$ $20 \mathrm{~m} \mathrm{~d}^{-1}$. Thus $15 \mathrm{~d}$ are required for transport of organic matter from subsurface layers $(100 \mathrm{~m}$ deep) down to the tunicate stratum $(400 \mathrm{~m})$. Our calculation concerns the high density estimate of tunicates, because they exhibited a patchy distribution which may correspond to the non-homogeneous arrival of food particles. On the other hand, the proximity of mature individuals may be considered as important for the preservation of the population (Holland et al. 1988). As we have assumed that no organic carbon of digestible size is leaving the midwater tunicate layer, our vertical flux value should be an underestimate.

The downward movement of particulate matter can be generated by vertical sedimentation, or by active transport induced by the frontal secondary circulation. The sedimentation rate of living and senescent algal cells of ingestible diameter ( 2 to $40 \mu \mathrm{m}$ for larvaceans) varies from 1 to $5 \mathrm{~m} \mathrm{~d}^{-1}$. This rate can however vary (Smayda 1971, Bienfang 1980, 1981, Smayda \& Bienfang 1983). The rate is insufficient to support nutritional needs of midwater filter-feeders at maximal observed concentrations and does not support a vertical sedimentation hypothesis. In the case of active transport, organic particles are moved from subsurface layers about 18 miles offshore to midwater depths at Stns 1 and 2 (6 and 8 miles) nearshore along the inclined isopycnals. The vertical distribution of microphytoplankton (MPH) at Stn 3 (Fig. 2) agrees with the scheme suggested for a vertical circulation of the $\mathrm{Li}$ guro-Provencal sea front (Boucher et al. 1987): the high values of MPH observed $300 \mathrm{~m}$ deep at Stn 3,418 m deep at Stn 2 and $450 \mathrm{~m}$ deep at Stn 1 could be indicative of the downwelled water mass due to frontal circulation and may constitute a nutritional source for midwater communities at Stns 1 and 2 . The second peak observed at $600 \mathrm{~m}$ (Stn 3) and the high value of MPH at $680 \mathrm{~m}$ (Stn 4) could indicate deep closure of the offshore convection cell or diffusion and sedimentation of living and non-living particles downwelled by the frontal circulation in the weakly stratified water mass (Fig. 2). As the deep closure flow cannot be measured directly by conventional methods such as with current meters or by the use of tracers, we suggest that the midwater larvaceans can be considered as indicators of layers rich in organic matter, and in the case described above, indicate the deep closure of the secondary circulation cell.

Karl \& Knauer (1984), analyzing sediment trap data from northeast Pacific, found midwater layers containing high concentrations of suspended particulate matter. They suggested that the accumulation of organic matter is the result of in situ metabolic activity, but the question concerning the source of carbon supporting this activity remained open.

The slow sinking rate of small particles and the strong vertical stratification of marine snow and pico-, nano- and microplankton lead us to conclude that the existence of midwater filter-feeder populations in the Ligurian frontal zone is closely related to an downward convective flux of organic matter from subsurface layers to midwater depths. The population of the new mesopelagic larvacean Oikopleura villafrancae is associated with this persistent convergent flow which produces localized concentrations of food particles. It is not yet clear if the population dynamics of this new species are controlled exclusively by the frontal structure.

Acknowledgements. We thank M. Youngbluth for his help in detritus sampler supply and adaptation, P. Chang, R. Fenaux, N. Fisher, P. Nival, F. Rassoulzadegan, A. Sournia, M. Youngbluth and anonymous reviewers for constructive comments on the manuscript, I. Palazzoli for technical support in the field and laboratory and the crews of submersible and ships aboard 'Cyana', 'Le Suroit' and 'Korotneff' This work was supported by FRONTAL (JGOFS/France), GDR P4 and URA 716 contributions.

\section{LITERATURE CITED}

Alldredge, A. (1976). Field behavior and adaptive strategies of appendicularians (Chordata: Tunicata). Mar Biol. 38: 29-39

Alldredge, A. (1981). The impact of appendicularian grazing on natural food concentration in situ. Limnol. Oceanogr. 26: $247-257$

Alldredge, A., Youngbluth, M. J. (1985). The significance of macroscopic aggregates (marine snow) as sites for heterotrophic bacterial production in the mesopelagic zone of the subtropical Atlantic. Deep Sea Res. 32: 1445-1456

Andersen, V. (1985). Filtration and ingestion rates of Salpa fusiformis Cuvier (Tunicata: Thaliacea): effects of size, individual weight and algal concentration. J. exp. mar. Biol. Ecol. 87: 13-29

Barham, E. G. (1979). Giant larvacean houses. Science 205: $1129-1131$

Béthoux, J. P., Prieur L. (1984). Hydrologie et circulation en Méditerranée Nord-Occidentale. In: Bizon, J. J., Burollet, P. F. (eds.) Ecologie des mi.croorganismes en Méditerranée occidentale. ASTP, Paris, p. 13-22

Béthoux, J. P., Prieur, L., Bong, J. H. (1988). Le courant Ligure au large de Nice. Oceanol. Acta 9: 59-67

Bienfang, P. K. (1980). Phytoplankton sinking rates in oligotrophic waters off Hawaii, USA. Mar. Biol. 61: 69-77

Bienfang, P. K. (1981). Sinking rates of heterogeneous, temperate phytoplankton populations. J. Plankton Res. 3: $235-253$

Boucher, J., Ibanez, F., Prieur, L. (1987). Daily and seasonal variations in the spatial distribution of zooplankton populations in relation to the physical structure in the Ligurian Sea Front. J. mar Res. 45: 133-173

Braconnot, J. C. (1971). Contribution à l'étude biologique et écologique des tuniciers plagiques salpides et doliolides. Vie Milieu 22: 257-286 
Braconnot, J. C., Choe, S. M., Nival, P. (1988). La croissance et le développement de Salpa fusiformis Cuvier (Tunicata, Thaliacea). Ann. Inst. Océanogr., Paris 64: 101-114

Bruland, K. W., Silver, M. W. (1981). Sinking rates of fecal pellets from gelatinous zooplankton (salps, pteropods, doliolids). Mar Biol. 63: 295-300

Davoll, P. J., Silver, M.W (1986). Marine snow aggregates: life history sequence and microbial community of abandoned larvacean houses from Monterey Bay, California Mar Ecol. Prog. Ser. 33: 111-120

Deibel, D. (1985). Blooms of pelagic tunicate, Dolioletta gegenbaueri: are they associated with Gulf Stream frontal eddies? J. mar Res. 43: 211-236

Deibel, D. (1986). Feeding mechanism and house of the appendicularian Oikopleura vanhoeffeni. Mar. Biol. 93: $429-436$

Deibel, D. (1988). Filter feeding by Oikopleura vanhoeffeni: grazing impact on suspended particles in cold ocean waters. Mar Biol. 99: 177-187

Deibel, D., Turner, J. T. (1985). Zooplankton feeding ecology: contents of fecal pellets of the appendicularian Oikopleura vanhoeffeni. Mar. Ecol. Prog. Ser 27: 67-78

Fenaux, R. (1976). Cycle vital d'un appendiculaire Oikopleura dioica Fol. 1872. Description et biologie. Ann. Inst. Océanogr., Paris 52, 1: 89-101

Fenaux, R. (1985). Rhythm of secretion of oikopleurids houses. Bull. mar. Sci. 37: 498-503

Fenaux, R., Bedo, A., Gorsky, G. (1986). Premières données sur la dynamique d'une population d'Oikopleura dioica Fol, 1872 (Appendiculaire) en élevage. Can. J. Zool. 64 $1745-1749$

Fenaux, R., Youngbluth, M. J. (1990). A new mesopelagic appendicularian, Mesochordeus bahamasi gen. nov., sp. nov. J. mar biol. Ass. U.K. 70: 755-760

Flood, P. R. (1979). Filters characteristics of appendicularian food catching nets. Experientia 34: 173-175

Fowler, S. W., Buat-Ménard, P., Yokoyama, Y., Ballestra, S. Holm, E., Nguyen, H. V (1987). Rapid removal of Chernobyl fallout from Mediterranean surface waters by biological activity. Nature, Lond. 329: 56-58

Fuhrman, J. A., Azam, F. (1980). Bacterioplankton secondary production estimates for coastal waters of British Columbia, Antarctica and California. Appl. environ. Microbiol. 39: $1085-1095$

Gorsky, G. (1980). Optimisation des cultures d'appendiculaires. Approche du metabolisme de $O$. dioica. Thése Doctorate de $3^{\mathrm{e}}$ cycle. Université de P. et M. Curie Paris VI

Gorsky, G., Fisher, F. S., Fowler, S. W. (1984). Biogenic debris from the pelagic tunicate, $O$. dioica, and its role in the vertical transport of a transuranium element. Estuar. coast. Shelf Sci. 18: 13-23

Gorsky, G., Palazzoli, I. (1989). Aspects de la biologie de l'appendiculaire Oikopleura dioica Fol, 1872 (Chordata: Tunicata). Oceanis 15: 39-49

Hamner, W. M., Madin, L. P., Alldredge, A. L., Gilmer, R. W. Hamner, P. P. (1975). Underwater observations of gelatinous zooplankton: sampling problems, feeding biology and behavior. Limnol. Oceanogr 20:907-917

Harbison, G. R., Gilmer, R. W. (1976). The feeding rates of the pelagic tunicate Pegea confederata and two other salps. Limnol. Oceanogr. 21: 517-528

Harbison, G. R., McAlister, V L. (1979). The filter-feeding rates and particle retention efficiencies of three species of Cyclosalpa (Tunicata, Thaliacea). Limnol. Oceanogr 24: 875-892

Heron, A. C. (1972). Population ecology of a colonizing species: the pelagic tunicate Thalia democratica I. Indi- vidual growth rates and generation time. Oecologia (Berl.) 10: $269-293$

Heron, A. C., Benham, E. E. (1985). Life history parameters as indicators of growth rate in three salp populations. $J$. Plankton Res. 7. 365-379

Holland, L. Z., Gorsky, G., Fenaux, R. (1988). Fertilisation in Oikopleura dioica (Tunicata, Appendicularia): acrosome reaction and sperm-egg fusion. Zoomorphology 108: 229-243

Iseki, K. (1981). Particulate organic matter transport to the deep sea by salp fecal pellets. Mar Ecol. Prog. Ser. 5 $55-60$

Karl, D. M., Knauer, G. A. (1984). Vertical distribution, transport, and exchange of carbon in the northeast Pacific Ocean: evidence for multiple zones of biological activity Deep Sea Res. 31: 221-243

Knoechel, R., Steel-Flynn, D. (1989). Clearance rates of Oikopleura in cold coastal Newfoundland waters: a predictive model and its trophodynamic implications. Mar Ecol. Prog. Ser. 53: 257-266

Laval, Ph., Braconnot, J. C., Carré, C., Goy, J., Mills, C., Morand, P. (1989). Small scale distribution of macroplankton in the Ligurian Sea (Mediterranea) as observed from the manned submersible CYANA. J. Plankton Res. 11. $665-675$

Le Borgne, R. (1983). Note sur les proliférations de Thaliacés dans le golf de Guinée. Océanogr trop. 18: 49-54

Le Borgne, R., Moll, Ph. (1986). Growth rates of the salp Thalia democratica in Tikehau atoll (Tuamotu Is.). Océanogr trop. 21. 23-29

Mackie, G. O. (1985). Midwater macroplankton of British Columbia studied by submersible PISCES IV J. Plankton Res. 7: 753-777

Mackie, G. O., Mills, C. E. (1983). Use of the PISCES IV submersible for zooplankton studies in coastal waters of British Columbia. Can. J. Fish. Aquat. Sci. 40: 763-766

Madin, L. P. (1982). Production, composition and sedimentation of salp pellets in oceanic waters. Mar Biol. 67. 39-45

Madin, L. P. Cetta, C. M. (1984). The use of gut fluorescence to estimate grazing by oceanic salps. J. Plankton Res. 6 475-497

Madin, L. P., Harbison, G. R. (1978). Bathocyroe fosteri gen nov. sp. nov. a mesopelagic ctenophore observed and collected from a submersible. J. mar biol. Ass. U.K. 58 $559-564$

Mills, C. E., Goy, J. (1988). In situ observations of the behavior of the mesopelagic Solmissus Narcomedusae (Cnidaria Hydrozoa). Bull. mar Sci. 43: 914-937

Mills, C. E., Larson, R. J., Youngbluth, M. J. (1987). A new species of coronate scyphomedusa from Bahamas, Atorella octogonos, new species. Bull. mar. Sci 40:423-427

Mullin, M. W. (1983). In situ measurement of filtering rates of the salp. Thalia democratica, on phytoplankton and bacteria. J. Plankton Res. 5: 279-288

Paffenhofer, G. A. (1976). On the biology of Appendicularia of the south-eastern North Sea. In: Persoone, G., Jaspers, E. (eds.) Proc. 10th Eur. Mar. Biol. Symp., Vol. 2. Universa Press, Wetteren, 437-455

Porter, K. G., Feig, Y. S. (1980). The use of DAPI for identifying and counting aquatic nanoflora. Limnol. Oceanogr. 25 : 943-948

Prieur, L., Raunet, J., Taillez, D. (1990). Radiale PROS VI 1981-1989. Rapport interne L.P.C.M. (Laboratoire de Physique et Chimie marines), $600 \mathrm{p}$.

Pugh, P. R., Harbison, G. R. (1987). Three new species of prayine siphonophore (Calycophorae, Prayidae) collected by submersible, with notes on related species. Bull. mar Sci. $41 \quad 68-91$ 
Pugh, P. R., Youngbluth, M. J. (1988). A new species of Halistema (Siphonophora, Physionectae, Agalmidae) collected by submersible. J. mar. biol. Ass. U.K. 68: 1-14

Putt, M., Stoecker, D. K. (1989). An experimentally determined carbon volume ratio for marine oligotrichous' ciliates from estudrine and coastal waters. Limnol. Oceanogr. 34: 1097-1103

Silver, M. W., Alldredge, A. L. (1981). Bathypelagic marine snow: deep-sea algal and detrital community. J. mar Res. 39: $501-530$

Seki, H. (1973). Red tide of Oikopleura in Saanich Inlet. Bull. Soc. franco-jap. Océanogr. 11: 153-159

Smayda, T J. (1971). Normal and accelerated sinking of phytoplankton in the sea. Mar Geol. 11: 105-122

Smayda, T. J., Bienfang, P. K. (1983). Suspension properties of various phyletic groups of phytoplankton and tintinnids in an oligotrophic, subtropical system. P.S.Z.N.I.: Mar Ecol. 4: $289-300$

Sournia, A., Brylinsky, J.-M., Dallot, S., Le Corre, P., Leveau, M., Prieur, L., Froget, C. (1990). Fronts hydrologiques au large des côtes françaises: les sites-ateliers du programme Frontal. Oceanol. Acta 13: 413-438

Strathmann, R. R. (1967). Estimating the organic carbon content of phytoplankton from cell volume or plasma volume. Limnol. Oceanogr. 12: 411.-418

Suzuki, N., Kato, K. (1953). Studies on suspended materials.

This article was submitted to the editor
Marine snow in the sea. I. Sources of marine snow. Bull. Fac. Fish. Hokkaido Univ. 4: 132-135

Taguchi, S. (1982). Seasonal study of fecal pellets and discarded houses of appendicularia in a subtropical inlet, Kaneohe Bay, Hawaii. Estuar. coast. Shelf Sci. 14: 545-555

Tietze, R. C., Clark. A. M. (1986). Remotedly operated tools for undersea vehicles. In: McGuiness, $T$ (ed.) Current practices and new technology in ocean engineering. American Society of Mechanical Engeneers, New York, p. 219-223

Verity, P. G., Langdon, C. (1984). Relationships between lorica volume, carbon, nitrogen, and ATP content of tintinnids in Narragansett Bay. J. Plankton Res, 66: 859-868

Youngbluth, M. J. (1984). Water column ecology: in situ observations of marine zooplankton from a manned submersible. In: Fleming, N. C. (ed.) Divers, submersibles, and marine science. Mem. Univ. Newfld. Occ. Pap. Biol. 9: $45-57$

Youngbluth, M. J., Bailey, T. G., Jacoby, C. A. (1990). Biological explorations in the mid-ocean realm: food webs, particle flux, and technological advancements. In: Lin, Y. C., Shida, K. K. (eds.) Proc. 2nd Int Symp. on Man in the Sea, Honolulu, Hawaij. Best Publishing, p. 191-208

Youngbluth, M. J., Kremer, P., Bailey, T G., Jacoby, C. A. (1988). Chemical composition, metabolic rates and feeding behavior of midwater ctenophore Bathocyroe fosteri. Mar. Biol. 98: 87-94

Manuscript first received: February 6, 1990

Revised version accepted: April 23, 1991 